\begin{tabular}{|c|c|}
\hline ב & $\begin{array}{c}\text { International Journal of Current Research } \\
\text { and Academic Review }\end{array}$ \\
\hline $\begin{array}{l}\text { EXCELLENT } \\
\text { PUBLISHERS }\end{array}$ & $\begin{array}{c}\text { ISSN: 2347-3215 (Online) Volume } 6 \text { Number } 7 \text { (July-2018) } \\
\text { Journal homepage: http://www.ijcrar.com }\end{array}$ \\
\hline
\end{tabular}

doi: https://doi.org/10.20546/ijcrar.2018.607.007

\title{
Stress and Associated Factors as a Predictor Variable on Academic Achievement among Students in Ambo University, Ambo, Ethiopia
}

\author{
Muna Suleyiman* \\ Department of Early Childhood Care and Education, Ambo University, Ambo, Ethiopia
}

*Corresponding author

\section{Abstract}

Stress is a state of an individual that result from the interaction of the individual with the environment which is perceived as threatening or threat to the well-being. University students encounter a great deal of academic, personal and social stress during their academic activities. The purpose of the present study was to assess the effect of stress and associated factors on academic achievement among Ambo University students. Mixed method explanatory design was conducted on a sample of 343 students at Ambo University. Data were collected using the Student-life Stress Inventory. Descriptive statistics, independent t-test, ANOVA and Pearson correlation coefficient were utilized to analyze the collected data using SPSS version 20. As a result, the general life time prevalence of stress was $24.5 \%$. More specifically, fear of academic failure, fear of family disappointment, lack of motivation and interpersonal relationship problem were highly reported symptom of stress students. Likewise, academic overload, assignments timings, political situation of country, financial strain, high family expectations, study skill problem, being alone, procrastination, living away from home, difficulty reading materials, language barrier, acculturation, relationship with opposite sex, lack of entertainment in the University, lack of family support, time management problem, and lack of personal interest in their department were frequently reported causes of stress in the University respectively. In this study, the independent t-test result shows that there was a statistically significant mean difference in experiencing stress across students' sex and residential area. Besides, ANOVA result revealed that year of study, students' perceived social support and perceived parenting style of the respondents had a significant effect on stress. Also, a statistically significant negative and moderate relationship was reported between stress and academic achievement. To sum up, nearly one fourth of students were suffering from measureable stress. Therefore, Ambo University management shall strengthen the academic counseling and preventive mental health services for the students so as to provide a conducive learning environment.
\end{abstract}

\section{Introduction}

Worldwide, Universities are responsible for making sure that students have adequate knowledge and skill in their field before taking professional responsibilities. In order to achieve these goals, Universities typically use a

\section{Article Info}

Accepted: 04 June 2018

Available Online: 10 July 2018

\section{Keywords}

Stress; Students; Ambo University 
Abubakar, Dali, Razzaque, Habib and Haque, 2015). The high societal expectations on students to perform various undefined, inconsistent, and unachievable roles in the present socio-cultural, economic, and bureaucratic contexts of the society cause heavy stress on students (Lal, 2014). Studies revealed that students experience a relatively high level of personal distress with adverse consequences on academic performance, competency, professionalism, and health (Abdulghani et al., 2011 and Abdulghani et al., 2014).

Naturally, everyone needs a certain amount of pressure to perform at their best. But when pressures exceed a person's ability to cope, the result is stress. Prolonged stress can set up distress and shut down the ability to cope with ordinary situations causing illnesses. Stress is the wear and tear our bodies experience as we adjust to our continually changing environment; it has physical and emotional effects and can create positive or negative influence on us. As a positive influence, stress can help to compel us for action. As a negative influence, it can result in feelings of distress, rejection, anger, and depression, which in turn can lead to health problems (Behere et al., 2011).

Stress is inevitable in human life, given the conflict between our needs and the realities of our environment and its relationships. Stress is common problem of every individual particularly for University students. These students are a special group of people that are enduring a critical transitory period in which they are going from adolescence to adulthood and can be one of the most stressful times in a person's life (Buchanan, 2012). For many undergraduate students, University life is a major transition in their lives since they are accorded the chance to decide what to do without the undue influence of their parents. Hence, the students make various decisions regarding all aspects of their lives such as academics, social life, and leisure activities (Baker, 2003). However, amidst the new found freedom students have to struggle to meet the expectations of their parents which include expectations related to their academic performance (Smith and Renk, 2007). In addition, society believes that graduating from a high-ranking University is a passport to a good job, high salaries, and high social status (Leppink et al., 2016). As a result, the students are indirectly subjected to a variety of stressors mainly linked to academic success (Sreeramareddy et al., 2007). Attending University and embarking upon an academic career is a pleasurable and exciting experience for many people. For many students, however, the transition to University and pursuing academic career may prove far more stressful than exciting (Hystad et al., 2009).

University students encounter a great deal of academic, personal and social stress during their academic activities (Kuruppuarachchi et al., 2012). Previous research demonstrated that undergraduate students significantly experience stress (Eva et al., 2015). First-year University students were found to be particularly prone to high levels of stress (Yusoff et al., 2013 and Abdallah and Gabr, 2014). Many of students face culture shock as University life is different from school life. Kumar and Jejurkar (2005) concluded that academic factors were mainly responsible for a higher level of stress among undergraduate students. Although some degree of stress is essential to stimulate and motivate individuals to achieve their goals, stress can be a barrier for concentrating, problem solving, decision making, and other necessary abilities for students' learning (Ellawela and Fonseka, 2011).

Education in the University is generally perceived as being stressful. Due to this, the causes of stress have been studied in several studies (Robotham, 2008; Ong et al., 2009; Elizabeth, 2010 and McCann et al., 2013). These finding illustrated that students were prone to stress due to the transitional nature of University life, feeling of loneliness, sleepiness, low social support, nervousness and worrying of their result, making new friends, adjusting to a new city, and many other unexpected changes. Previous research also documented that time management difficulty, financial matters, interaction with lecturers, personal subjective goals, adjustment problem in the academic culture and lack of support system were highly reported causes to experience high level of stress in the University (Wilks, 2008). Along with this, Khan et al., (2013) also reported that admission process, high expectation of parents, unsuitable school timings, unbalanced student-teacher ratio, physical environment of classroom, unhealthy student teacher interaction, hard and fast rules of discipline, too many or complex assignments, teaching methodology, unconcerned teacher's attitude and overemphasis on weaknesses rather than acknowledging strengths were determinant factors for stress among University students. Stressors such as leaving home for the first time, writing academic papers, examinations and other requirements of academia are experienced as immensely stressful by many students (Robotham; 2008). For others, the sudden transition of the use of 
English language as a medium of instruction can also be a source of stress for students (Alginahi et al., 2009).

Stress is a key factor in the development of emotional difficulties and behavioral problems. Extreme stress often leads to serious health problems (Santrock, 2005).

Beyond this, stress contributes to develop the feeling of depressions, anxiety, diabetes, asthma, ulcers and headaches. Furthermore, stress among students results in impaired judgments, absenteeism, self-medication, and addiction to substances such as khat chewing, cigarette smoking, and alcohol drinking (O'Rourke et al., 2010).

Various researches have been conducted on the prevalence of stress level among students. For instance, Muhamad (2013) found that the prevalence of stress in Malaysia Medical students was 29.65\%. Moreover, prevalence of stress in Saudi Arabia was 57\% (Abdulghani, 2008). Additionally, the prevalence of stress among students was $41.9 \%$ in Malaysian (Sherina et al., 2004) and 61.4\% in Thai (Saipanish, 2003). Another cross-sectional study conducted by Bayram and Bilgel (2008) on 1617 university students aged between 17 and 26 years in Turkey found depression, anxiety and moderate to severe stress levels of $27.1 \%, 47.1 \%$ and $27 \%$.

In many empirical studies, the effects of sociodemographic variables on stress level among University students have been studied in developed and developing country intensively. These studies revealed that sex (Sulaiman et al., 2009; Omoniyi and Ogunsanmi, 2012; Mazumdar et al., 2012; Sani et al., 2012; Sharma et al., 2011; Bhosale, 2014 and Cheung et al., 2016), residential area (Tajularipin et al., 2009), year of study (Cheung et al., 2016), average monthly family income (Teh et al., 2015), students' perceived social support (Azila-Gbettor et al., 2015), and perceived parenting style (Tajularipin et al., 2009) had a statistical significant effect on stress among undergraduate students.

Most noticeably, many researchers have attempted to assess the relationship between level of stress and academic achievement of the students (Elliot et al., 2005; Choi et al., 2007 and Talib and Rehman, 2012). These study finding confirmed that high stress level were associated with low academic achievement. Studies over the years have also demonstrated that poor academic performance of student and stress was significantly correlated (Dusselier et al., 2005; Taylor and Owusi-
Banahana, 2010; Sohail, 2013; Ahmed et al., 2013 and Azila-Gbettor et al., 2015).

Regarding to the study area, Ambo University is located in Ambo town, the capital of West Shewa Zone of Oromia regional state. With a population of about fifty thousand, Ambo is situated only $112 \mathrm{~km}$ west of Addis Ababa. Ambo University, established in 1939, is one of the oldest higher learning institutions in Ethiopia. Currently, Ambo University runs three PhD programs, twenty six Masters Programs and fifty eighty Bachelor programs which are divided into nine colleges/institutes/schools. Besides its main campus at Ambo, the University also has three campuses - Awaro, Guder and Woliso. In the years to come, the University has the vision of becoming one of the most prestigious universities in the country excelling in academics, research and community service giving its utmost attention to quality education. In 2016/17 academic year, total of 15,328 students were enrolled into all colleges/institutes/schools in which the educational wastage rate was $3.2 \%$. In Ambo University, there is no structured and strengthened counseling service for students although many students have reported various stress symptoms. At this point, it is important to examine psychiatric morbidity among university students, since most life-time mental disorders have their first onset typically when subjects are at University. Stress has harmful effects on both individual and society. They can lead to negative outcomes, such as impaired normal functioning, burnout, and health problems. Undergraduate students in Ethiopia are not excluded in this situation.

The current study recognizes that stress is a serious issue that permeates university life and can have devastating effects. The research was developed from an interaction with students during the teaching/learning process and the observation that some were visibly suffering from stress. As far as the knowledge of the researchers is concerned, there were a few multicentre studies on stress among Ethiopian University students. Hence, previous research investigating students' stress in Ambo University proved limited although most students have visited the University's counseling service to obtain the psychological service for their stress. This study was done with the intention to provide baseline data not only for intervention and for future studies but also for Ethiopia authority to take initiative to safeguard the wellbeing of the future professional in various field of study. Here, lack of enough attention to this problem of students can result in the long-term prevalence of this 
psychological disorder. For this reason, the purpose of the present study was to assess the effect of stress and associated factors on academic achievement among Ambo University students to address the significant gap. For this reason, this study was intended to address the following basic research questions:

What is the prevalence of stress among students in Ambo University?

What are the determinant factors for stress among students in Ambo University?

Is there any a statistically significant mean difference in experiencing stress across socio-demographic characteristics of student?

Is there any a significant relationship between experiencing stress and student's academic achievement?

\section{Materials and Methods}

\section{Study design}

The purpose of the present study was to assess the effect of stress and associated factors on academic achievement among Ambo University students. To achieve this purpose mixed method Explanatory design was employed.

\section{Sampling and sample size determination}

The target population of this study was Ambo University Undergraduate students. According to Ambo University main registrar, 15,328 students were enrolled in 4 Campus in 2015/16 academic year. Specifically, 5726 students were enrolled in Ambo main campus; 5942, 1794 and 1866 students were enrolled in Awaro, Guder and Wolliso campus respectively. Following that 9 students were randomly selected from 58 departments. Finally, a pool of 403 students from 9 college/institute/schools was included in the study. However, among the 403 distributed questionnaires, data collectors could collect 343 properly filled questionnaires. The rest 60 questionnaires were discarded for incompleteness. Due to this, the study analysis was done based on the response of 343 study participants. Simple random sampling was used to recruit students from each college/institute/schools.

\section{Variables}

The dependent variables of this study were students' stress and academic achievement. The primary independent variables were students' socio-demographic characteristics including sex, age, residential area, perceived social support, monthly income of the family and perceived parenting style.

\section{Data collection instruments}

Apart from self -developed unstructured and semi structured interview and document analysis, preestablished standardized questionnaires were used. Ultimately, the questionnaire has four sections where the first section collects data on students' socio-demographic characteristics. This includes sex, age, residential area, perceived social support, monthly income of the family and perceived parenting style. The second section of the questionnaire was adapted from Student-life Stress Inventory (SSI) which was developed by Gadzella (1991). Student-life Stress Inventory (SSI) was designed to assess the students' perceived academic stress and reactions to stress. There are 51 items arranged on a Likert response format ( $1=$ never true to $5=$ always true) that assessed five categories of academic stressors (frustrations, conflicts, pressures, changes, and selfimposed), and four categories describing reactions to stressors (physiological, emotional, behavioral, and cognitive). The items were summed for each subsection to get a total score in all nine categories. A higher score was indicative of greater stress and reactions to stress.

Internal consistency estimates ranged from 0.69 to 0.82 on the nine categories of stress (Misra and McKean, 2000). The original rating scale was highly adapted into 30 items for measuring stress among students. The third section collects qualitative data through self-developed interview and FGD questions. Finally, data on academic achievement were collected. To measure students' academic achievement, Grade Point Average (GPAs) of students in their year (s) of study in University in the previous semester was referred in 2016/17 academic year.

To test the reliability and validity, the pilot study was conducted on 60 Undergraduate University College students. Before collecting the final data, the tools were translated in to Amharic and Afan Oromo language. Content validity of the English, Amharic and Afan Oromo language version was assessed by three counseling psychologists from Ambo University. The translation consistency of the instrument was also examined by three language experts from Ambo University. Based on the comments and suggestions of the experts, changes were made in wording of four stress items on Afan Oromo version of the tool. In the pilot 
study, the reliabilities of the tools were found to be 0.916 for Student-life Stress Inventory.

\section{Data collection procedures}

The data was collected by administering the scale in a group to the student participants. The respondents were instructed to complete the scale by giving a response to every item of scale. To collect the data for the study, four supervisors were dispatched in which one supervisor for each study site were assigned. The role of supervisors was to train data collectors, oversee participant recruitment and data collection and checking and controlling data quality. A total of 20 data collectors (five for each campus) with at least a diploma level training mainly in the social sciences were recruited. Half-day training was provided for the data collectors on the purpose of the study, the contents of the data collection instruments, ethical matters, and on how to recruit and approach participants. The data- collection process was closely followed-up by the supervisors.

\section{Data analysis}

The collected data were analyzed descriptively to determine respondents' stress level and the source(s) of stress. Descriptive statistics (percentages, crosstabulations, mean and standard deviation) and inferential statistics (independent sample t- test, Pearson correlation coefficient, and ANOVA) were used to see the effect of socio-demographic variables on students' stress level. Correspondingly, the qualitative data were also analyzed. All data were analyzed using Statistical Package for Social Science (SPSS) for window version 20.

\section{Ethical considerations}

Oral as well as written informed consent was secured from the respondents. In addition, written permission was obtained from the respective officials of the institutions and organizations where the respondents were recruited based on an official request letter issued by Ambo University.

\section{Results and Discussion}

\section{Demographic characteristic of the respondents}

As can be presented from table 1, out of the total three hundred forty three students, 190 (55.4\%) were males and 153 (44.6\%) were females. Besides, the mean age of students was $20.22(\mathrm{SD}=1.411)$ where the minimum and maximum ages were 18 and 25 respectively. Regarding to students' year of study in the University, of all the respondents, almost 120 (35\%) were first year; 69 (20.1\%) were second year; 84 (35.5\%) were third year; $42(12.2 \%)$ were fourth year and $28(8.2 \%)$ were fifth year students. With regard to the residential area of respondents, 125 (36.4\%) were from urban and 218 $(63.6 \%)$ were from rural area. Hence, the students perceived that parents' support their children in different level. Accordingly, 120 (35.0\%), 114 (33.2\%), 60 $(17.5 \%)$ and $49(14.5 \%)$ of respondents perceived that they had good social support, no social support, a little bit social support, and very good social support respectively. Moreover this, with regard to students' parent income, 130 (37.9\%) of students' parent monthly income were considered as lower income group. Majority of them 171 (49.9\%) were perceived as middleincome groups followed by 42 (12.2\%) higher income groups.

\section{General prevalence of stress among undergraduate students in Ambo University}

As can be shown from table 2, out of 343 respondents, 71(20.7\%), $118(34.4 \%), 70(20.4 \%)$, and $84(24.5 \%)$ of students had found to be minimal, mild, moderate and severe level of stress respectively. For this reason, the general lifetime prevalence of stress was $24.5 \%$.

More specifically, fear of academic failure, fear of family disappointment on the result of students, lack of motivation and personal relationship were highly reported symptom of stress among Ambo University students.

According to crosstab result, even higher prevalence of stress were found among students who came from rural area, students with authoritarian parenting style, students with no perceived social support, first year and female students.

\section{Determinant factors for stress among students in the University}

In this study, among 343 respondents, most of them reported many determinant factors that trigger students' level of stress. List of reasons: academic overload (90.3\%), projects or assignments timings and deadlines $(88.3 \%)$, political situation of country $(87.4 \%)$, financial strain $(86.8 \%)$, high family expectations $(84.2 \%)$, study skill problem (83.9\%), being alone (82.2\%), procrastination $(79.3 \%)$, living away from home 
$(78.7 \%)$, difficulty reading materials $(76 \%)$, language barrier (63.6\%), acculturation (55.4\%), relationship with opposite sex (49.9\%), lack of entertainment in the University (46.6\%), lack of family support (42.2\%), difficulty with the journey back home $(37.9 \%)$, inability to socialize with peers (35\%), adjustment with roommate $(31.3 \%)$, family problems $(30.6 \%)$, time management problem $(24.5 \%)$, and lack of personal interest in their department $(20.1 \%)$ were frequently reported source of stress among University students respectively.

\section{Comparisons of stress among students across sex and residential area}

As can be verified from table 3 , there is a statistically significant mean difference in experiencing stress among male and female students $(\mathrm{t}(341)=-4.134, \mathrm{P}<0.05)$. Here, the mean score of stress for female students $(\mathrm{M}=82.09, \mathrm{SD}=19.25)$ was higher than male students $(\mathrm{M}=74.28, \mathrm{SD}=15.75)$.

This implies that females were highly vulnerable than male students for stress. Moreover, the result of independent t-test indicate that there was a statistically significant mean difference in experiencing stress among students whose residential area were urban and rural $(\mathrm{t}(341)=-17.656, \mathrm{p}<0.05)$. Also, the mean score of stress disorder for students whose residential area were rural $(\mathrm{M}=87.07, \mathrm{SD}=14.121)$ was higher than students whose residential area were urban $(\mathrm{M}=61.54, \mathrm{SD}=10.382)$.

Comparisons of students' stress level across year of study, perceived social support, income of the family and perceived parenting style

As can be seen from table 4, the mean stress score of first year students $(\mathrm{M}=93.76, \mathrm{SD}=15.84)$ was higher than second year $(\mathrm{M}=77.63, \mathrm{SD}=17.13)$, forth year $(\mathrm{M}=76.48$, $\mathrm{SD}=15.67)$, fifth year $(\mathrm{M}=76, \mathrm{SD}=11.01)$ and third year students $(\mathrm{M}=72.30, \mathrm{SD}=19.67)$. The difference was a statistically significant $(\mathrm{F}(4,337)=12.052, \mathrm{p}<0.05)$. Furthermore, the Bonferroni post hoc multiple comparisons result shows that first year students reported highly significant mean difference on stress symptoms as compared to second year $(\mathrm{p}<0.05)$, third year $(\mathrm{p}<0.05)$, forth year $(\mathrm{p}<0.05)$ and fifth year students $(\mathrm{p}<0.05)$. On the other hand, second year students had no mean difference on stress as compared to third year $(p>0.05)$ and fifth year students $(\mathrm{p}>0.05)$.

As it is shown from table 4, statistical significant mean differences were not observed in experiencing stress across respondents' monthly family income (F $(2,340)$ $=3.423, \mathrm{p}>0.05$ ). However, the mean stress score of respondents with middle family income $(\mathrm{M}=80.14$, $\mathrm{SD}=18.17$ ) was higher than respondents with lower monthly family income $(\mathrm{M}=76.21, \mathrm{SD}=17.73)$ and respondents with higher family income $(\mathrm{M}=73.31$, $\mathrm{SD}=15.43$ ).

Moreover, students' perceived social support had significant effect on students' stress symptoms (F (3, $338)=100.659, p<0.05)$. Furthermore, Bonferroni post hoc multiple comparisons revealed that respondents with no perceived social support demonstrated significant mean difference on stress as compared with respondents with a little bit $(\mathrm{p}<0.05)$, good $(\mathrm{p}<0.05)$ and very $\operatorname{good}(\mathrm{p}<0.05)$ social support. The mean stress score of respondents with no perceived social support ( $M=94.78$, $\mathrm{SD}=11.48$ ) was higher than respondents with a little bit social support $(\mathrm{M}=77.63, \mathrm{SD}=9.02)$, very good social support $(\mathrm{M}=68.73, \mathrm{SD}=16.77)$ and good social support $(\mathrm{M}=67.21, \mathrm{SD}=12.71)$.

Additionally, a statistical significant mean differences were observed on perceived parenting style of the respondents in experiencing stress symptoms $(\mathrm{F}(3,339)$ $=45.881, \mathrm{p}<0.05)$. To investigate further, the Bonferroni post hoc multiple comparisons result shows that respondents with authoritative parenting style reported highly significant mean difference on stress symptoms as compared to respondents with permissive $(\mathrm{p}<0.05)$ and negligent $(\mathrm{p}<0.05)$ parenting style.

On the other hand, respondents with authoritarian parenting style had no mean difference on stress as compared to respondents with permissive $(p>0.05)$ and negligent $(p>0.05)$ parenting style. The mean stress score of respondents with authoritarian parents $(\mathrm{M}=86.56, \mathrm{SD}=15.61)$ was higher than respondents with negligent parents $(\mathrm{M}=83.51, \mathrm{SD}=16.45)$, permissive parents $(\mathrm{M}=81.19, \quad \mathrm{SD}=12.77)$ and authoritative parenting style $(\mathrm{M}=64.69, \mathrm{SD}=15.47)$.

\section{Correlations between stress and academic achievement}

Table 5 shows us that stress was shown to be significantly correlated to academic achievement $(\mathrm{r}=$ 0.694, $p<0.05$ ). The relationship between stress and academic achievement was negative and moderate. This result indicates that when the students' level of stress increases, their academic achievement declines. 
Stress is a state of an individual that result from the interaction of the individual with the environment which is perceived as threatening or threat to the well-being. This study aimed to investigate the effect of stress and associated factors on academic achievement among Ambo University students. The finding of the present study shows that the general lifetime prevalence of stress was $24.5 \%$. This finding was pertinent with a research conducted by Melaku, Mossie, and Negash (2015) who found that the prevalence of stress in Ethiopia medical students was $52.4 \%$. This result was also in accordance with what was reported by Abdulghani (2008) who found that the prevalence of stress in Saudi Arabia was $57 \%$. Additionally, the prevalence of stress among students was $41.9 \%$ in Malaysian (Sherina et. al., 2004) and $61.4 \%$ in Thai (Saipanish, 2003). Another crosssectional study conducted by Bayram and Bilgel (2008) on 1617 university students aged between 17 and 26 years in Turkey found that stress levels was $27 \%$. This variation has been explained to be due to cultural differences, differences in the healthcare system, and differences in the population and the tools used in the study.
The finding of the existing study revealed that academic overload, projects or assignments timings and deadlines, political situation of country, financial strain, high family expectations, study skill problem, being alone, procrastination, living away from home, difficulty reading materials, language barrier, acculturation, relationship with opposite sex, lack of entertainment in the University, lack of family support, difficulty with the journey back home, inability to socialize with peers, adjustment with roommate, family problems, time management problem, and lack of personal interest in their department were frequently reported causes of stress in the University respectively. These findings agree with the outcome of other studies (Robotham, 2008; Ong, Bessie, and Cheong, 2009; Elizabeth, 2010 and McCann, Beddoe, McCormick, Kedge, Adamson and Huggard, 2013). These finding illustrated that college students were prone to stress due to the transitional nature of College/University life, feeling of loneliness, sleepiness, low social support, nervousness and worrying of their result, making new friends, adjusting to a new city, and many other unexpected changes.

Table.1 Socio-demographic characteristic of the respondents

\begin{tabular}{llcc}
\hline Demographic Variable & Categories & Frequency & Percentile \\
\hline Sex & Male & 190 & 55.4 \\
& Female & 153 & 44.6 \\
\hline Age & Mean SD & Minimum & Maximum \\
& 20.221 .411 & 18 & 25 \\
\hline Year of Study & $1^{\text {st }}$ Year & 120 & 35 \\
& $2^{\text {nd }}$ Year & 69 & 20.1 \\
& $3^{\text {rd }}$ Year & 84 & 24.5 \\
& $4^{\text {th }}$ Year & 42 & 12.2 \\
& $5^{\text {th } \text { Year }}$ & 28 & 8.2 \\
\hline Residential Area & Urban & 125 & 36.4 \\
& Rural & 218 & 63.6 \\
\hline Perceived Social Support & No social support & 114 & 33.2 \\
& A little bit social support & 60 & 17.5 \\
& Good social support & 120 & 35.0 \\
& Very Good social Support & 49 & 14.3 \\
\hline Monthly Income of the Family & Lower (less than 1999 birr) & 130 & 37.9 \\
& Middle (2000-5000 birr) & 171 & 49.9 \\
& Higher (greater than 5001birr) & 42 & 12.2 \\
\hline
\end{tabular}

Table.2 Prevalence of Stress among undergraduate students

\begin{tabular}{llcc}
\hline Variable & Category & Frequency & Percent \\
\hline Stress Level & Minimal Stress (30-49 Score) & 71 & 20.7 \\
& Mild Stress (50-80 Score) & 118 & 34.4 \\
& Moderate Stress (81-105 Score) & 70 & 20.4 \\
& Severe Stress (106-150 Score) & 84 & 24.5 \\
\hline
\end{tabular}


Table.3 Comparisons of stress across students' sex and residential area

\begin{tabular}{llccccc}
\hline Variable & Category & N & M & SD & t-test & p-value \\
\hline Sex & Male & 190 & 74.28 & 15.75 & -4.134 & 0.000 \\
& Female & 153 & 82.09 & 19.25 & & \\
\hline Resident area & Urban & 125 & 61.54 & 10.382 & -17.656 & 0.000 \\
& Rural & 218 & 87.07 & 14.121 & & \\
\hline
\end{tabular}

Table.4 ANOVA result of students' stress based on year of study, perceived social support, income of the family and perceived parenting style

\begin{tabular}{llccccc}
\hline Variable & Category & N & M & SD & F & p-value \\
\hline Year of study & $1^{\text {st }}$ Year & 120 & 93.76 & 15.84 & 12.052 & .000 \\
& $2^{\text {nd }}$ Year & 69 & 77.63 & 17.13 & & \\
& $3^{\text {rd }}$ Year & 84 & 72.30 & 19.67 & & \\
& $4^{\text {th }}$ Year & 42 & 76.48 & 15.67 & & \\
& $5^{\text {th }}$ Year & 28 & 76.00 & 11.01 & & \\
\hline Average Family & Lower (less than 1999 ETB) & 131 & 76.21 & 17.73 & 3.423 & 0.340 \\
Monthly Income & Middle (2000-5000 ETB) & 168 & 80.14 & 18.17 & & \\
& Higher (greater than 5000 ETB) & 44 & 73.31 & 15.43 & & \\
\hline Perceived Social & No social support & 114 & 94.78 & 11.48 & 100.659 & 0.000 \\
Support & A little bit social support & 60 & 77.63 & 9.02 & & \\
& Good social support & 120 & 67.21 & 12.71 & & \\
& Very Good social Support & 49 & 68.73 & 16.77 & & \\
\hline Perceived & Negligent & 29 & 83.51 & 16.45 & 45.881 & 0.000 \\
Parenting Style & Permissive & 73 & 81.19 & 12.77 & & \\
& Authoritarian & 125 & 86.56 & 15.61 & & \\
& Authoritative & 116 & 64.69 & 15.47 & & \\
\hline
\end{tabular}

Table.5 Correlation between stress and academic achievement of respondents

\begin{tabular}{llc}
\hline & & Academic achievement \\
\hline Stress Level & Pearson Correlation & $-0.694^{* * *}$ \\
& Sig. (2-tailed) & 0.000 \\
& N & 343 \\
\hline
\end{tabular}

Along with this, Khan, Altaf and Kausar (2013) also reported that admission process, high expectation of parents, unsuitable school timings, unbalanced studentteacher ratio, physical environment of classroom, unhealthy student teacher interaction, hard and fast rules of discipline, too many or complex assignments, teaching methodology, unconcerned teacher's attitude and overemphasis on weaknesses rather than acknowledging strengths were determinant factors for stress among University students. In this study, there was a statistically significant mean difference in experiencing stress among male and female students. Hence, the mean score of stress for females was higher than male students. This result was supported with that of (Sulaiman et al., 2009 and Cheung et al., 2016) who found that male and female students differ in experiencing stress. Other notable studies revealed that significant difference were observed between male and female on level of stress among University students (Mazumdar et al., 2012; Sani et al., 2012 and Sharma et al., 2011). Furthermore, female students were more prone to higher academic stress than their male counterparts (Rayle and Chung, 2008 and Bang, 2009). However, this finding was inconsistent with the previous study of Chen, Wong, Ran and Gilson (2009) who found that male students reported higher level of stress and worse psychological wellbeing. Contradicted with the present finding, Watson (2002); Omonyi et al., (2012) and Bhosale (2014) also claimed that no significant differences were observed between male and female on academic stress. The 
inconsistent data about gender difference were most likely explained by biological as well as socio-cultural factors.

Moreover, the result of this study depicted that the mean score of stress for students whose residential area were rural was higher than students whose residential area were urban. The mean difference is also statistically significant. This result was consistent with a study conducted by Tajularipin et al., (2009) who found that there is a significant difference between students in rural and urban secondary schools in the level of stress.

In the present study, the mean stress score of first year students was higher than second year, forth year, fifth year, and third year students. The difference was a statistically significant. The highest prevalence of stress was observed in first year students. This was because first year students started living in a new environment away from their family.

This finding was in agreement with results of various studies (Yusoff et al., 2011; Yusoff et al., 2010; Rahman et al., 2015 and Rahman et al., 2013). The finding of first-year undergraduate students having high stress level contradicts with the past research conducted by Habibah et al., (2011) who found that the final-year students were found to be the most stressful group among the undergraduate students. The possible explanations could be due to gradual adjustment to the learning environment and usually low failure rates in later years of the courses.

The finding shows that statistical significant mean differences were not observed in experiencing stress across respondents' monthly family income. However, the mean stress score of respondents with middle family income was higher than respondents with lower and higher monthly family income. This result was contradicted with a study of Teh et al., (2015) who found that there are significant associations between family income per-month with stress. Besides, Atalla and Altuwairqi (2017) also claimed that there was a significant relation between stress and average family monthly income.

Furthermore, the finding of the present study revealed that students' perceived social support had a significant effect on stress. Hence, students with no perceived social support demonstrated a significantly higher level of stress. This finding was similar with that of Cohen and Wills (1985) and Azila-Gbettor et al., (2015) who found that social support was found to buffer stress. Along with this, Solberg (1997) clarified that perceived social support moderates the relationship between stress and distress and those who had higher perception of social support had lower distress rating. Furthermore, Cohen (1988); Eckenrode and Wethington (1990); Coyne and Downey (1991) and Deihl et al., (1997) disclosed that parental social support has been correlated with level of stress among students.

This finding reveled that a statistically significant mean differences were observed in experiencing stress across perceived parenting style of the respondents. The mean stress score of respondents with authoritarian parents was higher than respondents with negligent, permissive and authoritative parenting style. The result was consistent with Tajularipin et al., (2009) who found that parenting style was factors that influence students' stress.

In the present study, there was a significant association between stress and students' academic achievement, but with negative correlation, indicating that when the level of stress increases, academic performance decreases which supports findings from previous study of Elliot $e t$ al., (2005); Choi et al., (2007) and Talib et al., (2012) who found that stress affects students' academic achievement. Hence, studies over the years have demonstrated that poor academic performance of student and stress was significantly correlated (Wombie, 2005; Dusselier et al., 2005; Taylor et al., 2010; Sohail, 2013; Ahmed et al., 2013 and Azila-Gbettor et al., 2015). However, this study finding was contradicted with various study findings (Choi et al., 2007; Habibah et al., 2011 and Rafidah et al., 2009). These findings reported that the relationship between stress and academic achievement was negative and weak $(r=-0.195)$. In line with this, a previous study conducted by Siraj et al., (2014) shows that respondents with high and severe stress level were observed to have higher cumulative grade point average (CGPA).

In this study, the general life time prevalence of stress was $24.5 \%$. More specifically, fear of academic failure, fear of family disappointment on the result of students, lack of motivation and personal relationship were highly reported symptom of stress among Ambo University students. According to crosstab result, even higher prevalence of stress were found among students who came from rural area, students with authoritarian parenting style, students with no perceived social support, first year and female students. Likewise, academic overload, projects or assignments timings and deadlines, political situation of country, financial strain, 
high family expectations, study skill problem, being alone, procrastination, living away from home, difficulty reading materials, language barrier, acculturation, relationship with opposite sex, lack of entertainment in the University, lack of family support, difficulty with the journey back home, inability to socialize with peers, adjustment with roommate, family problems, time management problem, and lack of personal interest in their department were frequently reported causes of stress in the University respectively. In this study, there was a statistically significant mean difference in experiencing stress across sex and residential area of students. Besides, the result of this study shows that year of study, students' perceived social support, and perceived parenting style of the respondents had significant effect on stress level of students. However, statistical significant mean differences were not observed on respondents' monthly family income in experiencing stress.

Finally, statistically significant negative and moderate relationships were observed between stress and academic achievement. These results that have several implications can be taken in consideration by administrators and academicians of the University in academic institutions to prevent mental illness or promote mental health among their students. There is no doubt that mental illness among university student ends with negative consequences on individual, family, and community. For instance, students with untreated stress are at high risk to harming themselves or others, dropping their educational programs, raising unemployment rate, and leading to extra burden on the families and society.

\section{Recommendation}

Based on the result of the study, the following recommendations shall be implemented by responsible stakeholders of the University. Counseling and preventive mental health services should be an essential part of the routine investigation of students. Along with this, actions should be taken to encourage the students to seek help on exposure to distress. Thus, administrators, academicians, and healthcare providers of the University can play a significant role in developing collaborative, multidimensional, and culturally sensitive preventive mental health programs to create a helpful academic context that promotes students' psychosocial wellbeing, improves their productivity, and enhances their success. To avoid the source of stress, the University management should be flexible in order to give attention for the interest of their students and not to make too much boring and tighten academic schedules. Also, mental health professionals like psychologists, social workers and psychiatrists shall give consecutive training on life skill, stress management, and adaptive coping mechanism.

\section{Limitation and Future Implication}

In conducting this study, the usage of a structured instrument, trained data collectors, and supervisors to collect data from randomly selected students decreases the likelihood of the occurrence of bias in the study.

However, although the Amharic and Afan Oromo version of the instrument had revealed good reliability and feasibility, it was too hard to be quite sure that the translated tool retained their original psychometric properties in different cultural backgrounds of the study sites.

Likewise, the researchers could not discuss this study finding with similar locally available study results. Due to this, it is difficult to generalize to other contexts. In line with this, further investigation would be recommended on the relationship between stress and depression, anxiety disorder, and substance abuse disorder among undergraduate University students.

\section{Conflict of Interest}

The authors declared no conflict of interest.

\section{Acknowledgment}

The authors would like to genuinely thank the participants and data collectors of the research.

\section{References}

Abdallah, R., and H. M. Gabr, "Depression anxiety and stress among first year medical students in an Egyptian public university," International Research Journal of Medicine and Medical Sciences, vol. 2, no. 1, pp. 11-19, 2014.

Abdulghani, H. (2008). Stress and depression among medical students: across sectional study at a medical college in Saudi Arabia. Pak J Med Sci; 24:12-7.

Abdulghani, H.M., AlKanhal, A.A., Mahmoud, E.S., Ponnamperuma, G.G., Alfaris, E.A. (2011). Stress and its effects on medical students: a cross-sectional study at a college of medicine in Saudi Arabia. J Health PopulNutr 29(5): 516. 
Abdulghani, H.M., Irshad, M., Al Zunitan, M.A., Al Sulihem, A.A., Al Dehaim, M.A., Al Esefir WA et al., (2014) Prevalence of stress in junior doctors during their internship training: a cross-sectional study of three Saudi medical colleges' hospitals. NeuropsychiatrcDis Treat 10:1879-1886.

Ahmed, U., A. Riazand and Ramzan, (2013).“Assessment of Stress and Stressors: A Study on Management Students", Interdisciplinary Journal of Contemporary Research in Business, 4(9): 687-699.

Alginahi, Y.M., Ahmed, M., Tayan, O., Siddiqi, A.A., Sharif, L., Alharby, A., and Nour, R. (2009). ICT students, stress and coping strategies: English perspective as a case study of midsize Middle Eastern University. Trends in Information Management, 5(2), 111 - 140.

Atalla, A., \&Altuwairqi, Y.A. (2017). Prevalence of Stress among Junior Medical Students, Taif University. J Community Med Health Educ 7: 537. doi: 10.4172/2161-0711.1000537

Baker, S.R. (2003). A prospective longitudinal investigation of social problem solving appraisals on adjustment to university, stress, health, and academic motivation and performance. Personality and Individual Differences, 35, 569-591.

Bang, E. (2009). The effects of gender, academic concerns, and social support on stress for international students. Retrieved April, 06, 2012 from https://mospace.umsystem.edu/

Bayram, N.; Bilgel, N. The prevalence and sociodemographic correlations of depression, anxiety and stress among a group of university students. Soc. Psychiatry Epidemiol. 2008, 43, 667-672.

Behere, S.P., Yadav, R., Behere, P.B. (2011). A comparative study of stress among students of medicine, engineering, and nursing. Indian $\mathbf{J}$ Psychol Med 33(2): 145-148. http://www.ncbi.nlm.nih.gov/pmc/articles/PMC327 $1488 /$

Bhosale, (2014). "A Study of Academic Stress and Gender Difference", Indian Streams Research Journal, 4(6): 1-4

Buchanan, J.L. (2012).Prevention of depression in the college student Population: a review of the literature. Arch Psychiatric Nurs 2012; 26(1): 2142.

Chen, H., Wong, Y., Ran, M., and Gilson, C, (2009). Stress among Shanghai University Students. Journal of Social Work. 9(3). pp. 323-344.

Cheung, Wong, Law, Karen, Tong, Ying and Yip (2016).Depression, Anxiety and Symptoms of Stress among Baccalaureate Nursing Students in Hong Kong: A Cross-Sectional Study: Int. J. Environ. Res. Public Health, 13, 779; doi: 10.3390/ijerph 13080779

Choi, Y. B., Abbott, T. A., Arthur, M. A., and Hill, D. (2007). Towards a future wireless classroom paradigm. International Journal of Innovation and Learning, 4(1), 14-25.

Cohen, S. (1988). Psychological model of social support in the etiology of physical disease. Health Psychology, 7, 269-297.

Cohen, S., and Wills, T. A. (1985).Stress, social support, and the buffering hypothesis. Psychological Bulletin, 98, 310-357.

Coyne, J. C., and Downey, G. (1991). Social factors and psychopathology: Stress, social support, and coping processes. Annual Review of Psychology, 42, 401 425.

Deihl, L. M., Vicary, J. R., and Deike, R. C. (1997). Longitudinal trajectories of self-esteem from early to middle adolescence and related psychosocial variables among rural adolescents. Journal of Research on Adolescents, 7(4), 393-411.

Dusselier, L., Dunn, B., Wang, Y., Shelley, M. C., and Whalen, D. F. (2005). Personal, health, academic, and environmental predictors of stress for residence hall students. Journal of American College Health, 54: $15-24$.

Eckenrode, J. E., and Wethington, E. (1990).The process and outcome of mobilizing social support. In S.E. Duck (Ed.), Personal relationships and social support (pp. 83-102). Newbury Park, CA: Sage.

Edem Maxwell Azila-Gbettor et al., (2015)"Stress and Academic Achievement: Empirical Evidence of Business Students in a Ghanaian Polytechnic: International Journal of Research in Business Studies and Management Volume 2, Issue 4,, PP 7898

Elizabeth, S. (2010). Stress in College: Common Causes of Stress in College http://www.cdc.gov/nasd/docs/d001201d001300/d001245/d001245.htmGraw Hill, Inc

Ellawela, Y.G., and Fonseka. P. (2011). Psychological distress, associated factors and coping strategies among female student nurses in the Nurses' Training School Galle. Journal of the College of Community Physicians of Sri Lanka. 16 (1), 23-29.

Elliot, A. J., Shell, M. M., Henry, K. B., and Maeir, M. A. (2005). Achievement goals, performance contingencies, and performance attainment: An experimental test. Journal of Educational Psychology, 97(4), 630-640. 
Eva, Islam, Mosaddek, Rahman, Rozario, Iftekhar, Ahmed, Jahan, Abubakar, Dali, Razzaque, Habib and Haque (2015) Prevalence of stress among medical students: a comparative study between public and private medical schools in Bangladesh: BMC Res Notes 8: 327

Gadzella, B. M. (1991). Student-Life stress inventory. Commerce, TX: Author.

Habibah E., Wong, S., and Maria, A. (2011). Stress and Academic Achievement among Undergraduate Students in University Putra Malaysia Procedia Social and Behavioral Sciences: 646-655

Hystad, S. W., Eid, J., Laberg, J. C., Johnsen, B. H., and Bartone, P. T. (2009). Academic stress and health: Exploring the moderating role of personality hardiness. Scandinavian Journal of Educational Research, 53, 421-429.

Khan, Altaf and Kausar (2013) Effect of Perceived Academic Stress on Students' Performance: FWU Journal of Social Sciences, Winter, Vol. 7, No. 2, 146-151

Kumar, S., and Jejurkar, K. (2005).Study of Stress Level in Occupational Therapy Students during their Academic Curriculum.The Indian Journal of Occupational Therapy, 37 (1), 5-14.

Kuruppuarachchi, K. A. J. M., Somerathna, S., Madurapperuma, B. D., and Talagala, I. M. M. (2012). Factors associated with psychological distress among B.Sc. undergraduates of the Open University of Sri Lanka. Annual Academic Sesssion, 2012, Open University of Sri Lanka.

Lal, K. Academic Stress among Adolescent in Relation to Intelligence and Demographic Factors. Am. Int. J. Res. Humanit. Arts Soc. Sci. 2014, 5, 123-129.

Leppink, E.; Odlaug, B.; Lust, K.; Christenson, G.; Grant, J. The Young and the Stressed. J. Nerv. Ment. Dis. 2016, 204, 931-938.

Mazumdar, H., D. Gogoi, L. Buragohain., and N. Haloi, (2012). "A Comparative Study on Stress and Its Contributing Factors among the Graduate and PostGraduate Students", Advances in Applied Science Research, 3(1): 399-406.

McCann CM, Beddoe E, McCormick K, Kedge PHS, Adamson C, Huggard J (2013) Resilient in health professions: a review of recent literature. Int $\mathbf{J}$ Wellbeing 3(1): 60-81. http://www.internationaljournalofwellbeing.org/inde x.php/ijow/article/view/153/311

Melaku, Mossie, and Negash (2015). Stress among Medical Students and Its Association with Substance Use and Academic Performance: Journal of Biomedical Education, Hindawi Publishing Corporation.

O'Rourke, M., S., Hammond, S., O'Flynn, and G. Boylan, (2010). "The medical student stress profile: a tool for stress audit in medical training," Medical Education, vol.44, no. 10, pp. 1027-1037, 2010.

Omoniyi, M.B.I., and J.O. Ogunsanmi, (2012). "Stress among Academic Staff in South West Nigeria", The African Symposium, 12(1): 126-132

Ong, Bessie and Cheong, K. C. (2009). Sources of stress among college students - The case of a credit transfer programme [Electronic version]. College Student Journal, 43(4).

Rafidah, K., Azizah, A., Norzaidi, M. D., Chong, S. C., \&Salwani, M. I. (2009). Stress and academic performance: empirical evidence from university students [Electronic version]. Academy of Educational Leadership Journal.

Rahman NIA, Ismail S, Ali RM, Alattraqchi AG, Dali WPEW, Umar BU et al., (2015) Stress among first batch of MBBS students of Faculty of Medicine and Health Sciences, Universiti Sultan Zainal Abidin, Malaysia: when final professional examination is knocking the door. Int Med J 22(4):1-6.

Rahman NIA, Ismail S, Seman TNABT, Rosli NFAB, Jusoh SABM, Dali WPEW et al., (2013) Stress among preclinical medical students of Universiti Sultan Zainal Abidin. J App Pharm Sci 3(11):076081

Rayle, A. D., and Chung, K. (2008). Revisiting first year college students' mattering: Social support, academic stress and the mattering experience. Journal of College Student Retention: Research, Theory and Practice, 9, 21-37.

Robotham, D. (2008). Stress among higher education students: Towards a research agenda. Higher Education, 56, 735 - 746.

Saipanish, R. (2003). Stress among Medical Students in a Thai Medical School, Medical Teacher, 25(5):502506.

Sani, M., Mahfouz, M.S., I. Bani, A.H., Alsomily, D., Alagiand N.Y., Alsomily. (2012). Prevalence of Stress among Medical Students in Jizan University, Kingdom of Saudi Arabia, Gulf Medical Journal, 1(1):19-25.

Santrock, J. (2005). Essential psychology. (2 $2^{\text {nd }}$ d.) McGrow Hill.

Sharma, B. R., Wavare, A., Deshpande, R., Nigamand R., Chandorkar, (2011). A Study of Academic Stress and Its Effect on Vital Parameters in Final Year Medical Students at SAIMS Medical College, 
Indore, Madhya Pradesh, Biomedical Research, 22 (3): 361-365

Sherina, M.S., Rampal, L, Kaneson, N. (2004). Psychological stress among Undergraduate medical students. Med J Malaysia 2004; 59: 207-11.

Siraj, H, H., A. Salam, R., Roslan, N, A., Hasan, T.H., Jin and M.N., Othman, (2014). Stress and its Association with the Academic Performance of Undergraduate Fourth Year Medical Students at University Kebangsaan Malaysia, The International Medical Journal Malaysia, 13(1): 19-24

Smith, T., and Renk, K. (2007). Predictors of academicrelated stress in college students: an examination of coping, social support, parenting, and anxiety. NASPA Journal, 44, 405-431.

Sohail, N. (2013). Stress and Academic Performance among Medical Students, Journal of the College of Physicians and Surgeons, 23 (1): 67-71

Solberg, V. S. (1997). Examination of self-efficacy, social support, and stress as predictors of psychological and physical distress among Hispanic college students. Hispanic Journal of Behavioral Sciences, 19(2), 182-201.

Sreeramareddy, C. T., Shankar, P. R., Binu, V. S., Mukhopadhyay, C., Ray, B., and Menezes, R. G. (2007). Psychological morbidity, sources of stress and coping strategies among undergraduate medical students of Nepal. BMC Medical Education, 7, 26.

Sulaiman, T., Hassan, A., Sapian, V. M., and Abdullah, S. K. (2009). The Level of Stress among Students in Urban and Rural Secondary Schools in Malaysia. European Journal of Social Sciences, 10(2), 179184.

Tajularipin, S., Aminuddin, H., Vizata, S., and Saifuddin, A. (2009). The level of stress among students in Urban and rural secondary schools in Malaysia. European Journal of Social Sciences. 10 (2). pp. 4365.

Talib, N., and Rehman MZU. (2012). "Academic performance and perceived stress among university students", Educational Research and Review Vol.
7(5), pp. 127 132, DOI: 10.5897/ ERR10.192. Retrieved from http://www.Academicjournals.org /err/PDF/Pdf\%202012/February/5\%20Feb

/Talib\%20and\%20 Zia-ur-Rehman.pdf

Taylor, M.F., and N.O. Owusi-Banahana, (2010). Stress among Part-Time Business Students. A Study in a Ghanaian University Campus, IFE Psychologia: An International Journal of Psychology, 18(1): 137157.

Teh, C.K., Ngo, C.W., Zulkifli, R.A., Vellasamy, R. and Suresh, K. (2015). Depression, Anxiety and Stress among Undergraduate Students: A Cross Sectional Study. Open Journal of Epidemiology, 5, 260-268.

Watson, R. L. (2002). A comparison of perceived stress levels and coping styles of junior and senior students in nursing and social work programs. Unpublished doctoral dissertation, Marshall University, Huntington,

Wilks, S. E. (2008). Resilience amid Academic Stress: The Moderating Impact of Social Support among Social Work Students. Advances in Social Work, 9(2), 106-125

Wombie, L.P. (2005). Impact of Stress Factors on College Students Academic Performance, Undergraduate Journal of Psychology, 16(1): 1623.

Yusoff MSB, Rahim AFA, Yaacob MJ (2010) Prevalence and sources of stress among Universiti Sains Malaysia medical students. Malays J Med Sci 17(1):30-37

Yusoff MSB, Yee LY, Wei LH, Siong TC, Meng LH, Bin LX et al., (2011) A study on stress, stressors and coping strategies among Malaysian medical students. Int J Stud Res 1(2):45-50.

Yusoff, A. F. Abdul Rahim, A. A. Baba, S. B. Ismail, M. N. Mat Pa, and A. R. Esa, "Prevalence and associated factors of stress, anxiety and depression among prospective medical students," Asian Journal of Psychiatry, vol. 6, no. 2, pp. 128 133, 2013.

\section{How to cite this article:}

Muna Suleyiman. 2018. Stress and Associated Factors as a Predictor Variable on Academic Achievement among Students in Ambo University, Ambo, Ethiopia. Int.J.Curr.Res.Aca.Rev. 6(7), 63-75.

doi: https://doi.org/10.20546/ijcrar.2018.607.007 